\title{
Toxic effects of different doses of cyclophosphamide on the reproductive parameters of male mice
}

\author{
Tatiane Yumi Nakamura Kanno, Lucimara Aparecida Sensiate, Natália Aparecida de Paula, Maria \\ José Sparça Salles*
}

Laboratory of Development Toxicology, Department of General Biology - CCB, State University of Londrina

\begin{abstract}
The cyclophosphamide is used in cancer treatment. The aim of this study was evaluating the effect of different doses of this drug on male mice reproductive parameters. The cyclophosphamide was administered in the doses $100,150,200$ e $250 \mathrm{mg} \cdot \mathrm{kg}^{-1}$, intraperitoneal route, for six weeks. As a result, it was observed a decrease in body mass and a decrease in testicles and kidney's weight, in all animals treated with cyclophosphamide. Only the groups that received the doses $100,150 \mathrm{mg} \cdot \mathrm{kg}^{-1}$ of cyclophosphamide were able to fertilize their females. There was higher incidence of post- implantation losses, reabsorptions and decrease in fetal viability in the group that received the dose of $150 \mathrm{mg} \cdot \mathrm{kg}^{-1}$. It was observed a reduction in epididymis and liver's weight of the animals treated with the doses 150,200 e $250 \mathrm{mg}^{\mathrm{kg}} \mathrm{kg}^{-1}$. Abnormal spermatozoa were found in the doses 200 e $250 \mathrm{mg} \cdot \mathrm{kg}^{-1}$. Based on the methodology used and results obtained, it was concluded that the cyclophosphamide was toxic, considering the decrease in animal's body mass and testicle's weight; promoted hepatotoxicity and nephrotoxic effect; influenced in the animals spermatogenesis taking them to infertility and/or subfertility; decreased fetal viability, despite it didn't cause significant malformations in the offspring.
\end{abstract}

Uniterms: Cyclophosphamide/effects. Cyclophosphamide/toxicity. Spermatogenesis/experimental study. Chemotherapeutics/adverse effects. Fertility/experimental study.

A ciclofosfamida é utilizada no tratamento de câncer. Este estudo visa avaliar os efeitos das diferentes doses do fármaco nos parâmetros reprodutivos de camundongos machos. A ciclofosfamida foi administrada nas doses de 100, 150, 200 e $250 \mathrm{mg} \mathrm{kg}^{-1}$, via intraperitoneal por seis semanas. Como resultado observou-se diminuição de massa corporal, redução no peso de testículos e rins em todos os animais tratados com a ciclofosfamida. Apenas os grupos que receberam as doses de 100 e $150 \mathrm{mg} \mathrm{kg}^{-1} \mathrm{do}$ quimioterápico foram capazes de fertilizar as fêmeas. Houve maior incidência de perdas pós-implantação, reabsorção e diminuição da viabilidade fetal no grupo que recebeu a dose de $150 \mathrm{mg} \mathrm{kg}^{-1}$. Observou-se redução nos pesos dos epidídimos e fígado dos animais tratados com as doses de 150,200 e $250 \mathrm{mg} \mathrm{kg}^{-1}$. Espermatozóides anômalos foram encontrados nas doses de 200 e $250 \mathrm{mg} \mathrm{kg}^{-1}$. Com base na metodologia empregada e nos resultados obtidos, conclui-se que a ciclofosfamida foi tóxica considerando-se a redução de massa corporal e o peso dos testículos dos animais; promoveu hepatotoxicidade e efeito nefrotóxico; influenciou na espermatogênese dos animais de forma a levá-los a um estado de infertilidade e/ou subfertilidade; diminuiu viabilidade fetal, entretanto não causou malformações significativas na prole.

Unitermos: Ciclofosfamida/efeitos. Ciclofosfamida/toxicidade. Espermatogênese/estudo experimental. Quimioterápicos/efeitos adversos. Fertilidade/ estudo experimental.

\section{INTRODUCTION}

The use of mutagenic, carcinogenic and cytotoxic agents in treatments for several types of cancer is parti-

*Correspondence: M. J. S. Salles. Departamento de Biologia Geral - CCB, Universidade Estadual de Londrina, Caixa Postal 6001 - 86051-990 - Londrina - PR, Brasil. E-mail: maze@uel.br cularly risky in men at reproductive age, and, possibly, it could lead to congenital malformation in the offspring. Some agents affect the fertility and other aspects of reproductive functions, for instance, treatments with anticancer drugs, such as cyclophosphamide, have been associated with oligospermia, azoospermia, seminiferous tubular atrophy (Fairley et al., 1972; Schamberg et al., 1981; 
Kelly et al., 1992) and increase in the levels of Follicle Stimulating Hormone (FSH) (Trasler et al., 1985). The cyclophosphamide is a nitrogenous mustard pertaining to the group of cytotoxic or cytostatic drugs, also known as antineoplastics (Bach, Strom, 1986). It integrates a subgroup of substances named alkylating agents, which are effective against slow-growing tumors that damage cells at any phase of cellular growth. The alkylating agents have the propriety to become strong electrophiles, by means of formation of intermediate carbon ions or transition complexes with target-molecules, which could include guanines and other components of DNA (Allison, 2000).

This agent is relatively inert until the binding phosphorus-nitrogen is broken by means of metabolism catalyzed by hepatic enzymes of Cytochrome P450, which are responsible for the reaction of initial drug activation. The activation occurs when the inactive cyclophosphamide is metabolized by $\mathrm{P} 450$ oxidase enzymes, being transformed into 4-hydroxycyclophosphamide that originates the aldophosphamide. The latter, by its time, is carried to other tissues, where it is converted into mustard phosphoramide (the effectively cytotoxic molecule) and acrolein, which is responsible for the adverse effects (Rang et al., 2007).

In the tumoral cells, the aldophosphamide undergoes spontaneous cleavage, with production of phosphoramine mustard and acrolein, being the former responsible for antitumoral effects through the alkylation of tumoral cells DNA, resulting in the crosslink of nucleic acids chains or in the binding of a nucleic acid to a protein. These alterations damage seriously the DNA molecule, resulting in the cellular death (Hardman, Limbird, 2003). The main action of cyclophosphamide occurs during the replication, when some parts of DNA are not paired and more susceptible to alkylating. The effects manifest themselves, however, during the $\mathrm{S}$ phase, causing a blockage in $\mathrm{G} 2$ and the subsequent cellular death (Rang et al., 2007).

The drug is a strong immunodepressive, acting in the cells with high mitotic activity, inhibiting as the humoral immune response, as the cellular one (Bach, Strom, 1986). Since its introduction in the clinical use, which occurred in 1958 (Chaube et al., 1967), the cyclophosphamide has been utilized in the treatment of both, malignant neoplasias and non-malignant neoplasias, such as rheumatic arthritis, as well as immunodepressive agent before organs transplantation (Anderson et al., 1995).

According to some authors (Fairley et al., 1972; Schamberg et al., 1981; Kelly et al., 1992) the cyclophosphamide induces alterations in human and rodent testicular functions, and promotes infertility. And, considering that the male partner contributes for a half of genetic informa- tion for the developing offspring, he should be examined as the responsible for teratogenesis and adverse alterations in the offspring development (Anderson, 2005).

The cyclophosphamide was chosen for this study because it is very clinically utilized in treatments of oncologic patients, and also because it is associated with variable periods of infertility in humans (Trasler et al., 1988). So, this present research had as purpose to evaluate the effects caused by cyclophosphamide administration, in different doses, on the reproductive development of male mice, as well as to evaluate the intrauterine growth and offspring malformations.

\section{MATERIAL AND METHODS}

Swiss mice (Mus musculus), being fifty males and one hundred females, sexually mature, with average weight of $30 \mathrm{~g}$ and coming from the Central Vivarium of the Biological Sciences Center of the State University of Londrina (Universidade Estadual de Londrina - UEL), were utilized for this study. The entire experiment was conducted according the norms of Ethics Committee in Animal Experimentation of UEL.

The animals were maintained separate, in cages of propylene with cap of zincified wire containing wood shavings, with water and rations freely. They passed by a three days period of acclimation in the sector vivarium, before treatment starting. During the experiment development, the animals were maintained in a controlled luminosity regimen, being utilized for that a photoperiod of 12 hours light/12 hours dark, with temperature around $22 \pm 2{ }^{\circ} \mathrm{C}$. After weighing, the males were distributed randomly in five experimental groups (with ten animals every one), as described as follows: the control group received PBS $0.1 \mathrm{~mL} / 10 \mathrm{~g}$ of body weight (b.w.) and the groups $\mathrm{C} 100, \mathrm{C} 150, \mathrm{C} 300$ and $\mathrm{C} 250$ received cyclophosphamide in the doses of $100 \mathrm{mg} \cdot \mathrm{kg}^{-1}$ (b.w.), $150 \mathrm{mg} \cdot \mathrm{kg}^{-1}$ (b.w.), 200 mg.kg ${ }^{-1}$ (b.w.) and 250 mg.kg-1 (b.w.), respectively. The concentrations were defined according the lower and higher doses found in reviewed literature (Schimenti et al., 1997; Fagundes et al., 2005), being chosen intermediate values between them.

The treatment was developed once a week, intraperitoneally (i.p.), during six weeks to embrace, at least, one spermatogenic cycle that, in mice, has the duration of 35 days (Adler, 2001). After the fifth treatment, every male was matched with two nullipara females. These animals remained together during a week, to enable the female passing a complete estral cycle joined to treated male.

The presence of vaginal "plug" indicated the starting of pregnancy period counting, being considered as 
Day 0 . At $17^{\text {th }}$ gestational day, the females were anesthetized by inhalation of ethylic ether, euthanized by cervical dislocation, and submitted to laparotomy for fetuses' withdrawal and counting of implantation sites and present reabsorptions number. The placentas were weighed in order to calculate the placental index. The fetuses were measured, weighed and fixed in Bodian's and Acetone solutions, for further analyses of visceral and skeletal malformations, respectively. The visceral analysis was done through the sectioning proposed by Barrow and Taylor (1969) for thorax and abdomen stu$\mathrm{dy}$, and by the strategic sectioning proposed by Wilson (1965) for head study. The fetuses fixed in acetone were submitted to the technique of Alizarin red described by Staples and Schnell (1964), for the development of skeletal analysis. In this analysis, the fetuses were evaluated by detection of skull, sternum, vertebras, ribs, pelvis, clavicle, phalanges, metacarpus and metatarsus according to the method of Taylor (1986). The visceral and fetal skeleton examinations were developed under stereomicroscopic magnifier.

The males were anesthetized by inhalation of ethylic ether and euthanized by cervical dislocation 24 hours after the last treatment, in the sixth week. Their heart, lungs, kidneys, liver and reproductive organs (testicles and epididymis) were removed and weighed and it was also developed the morphologic evaluation of spermatozoids contained in the epididymis, according methodology described by Wyrobek et al. (1983). The blades were prepared and stained with Shorr and 200 cells per animal were analyzed in optical microscopy using an amplification of x 1000 .

The statistical interpretation for parametric data was done through the ANOVA followed by Tukey test; and the data with non-parametric distribution were analyzed by Kruskal-Wallis and Dunn, using the statistical software "Instat", with significance level of 5\%.

\section{RESULTS}

The cyclophosphamide administered to adult male mice in concentration of $100 \mathrm{mg} \cdot \mathrm{kg}^{-1}, 150 \mathrm{mg} \cdot \mathrm{kg}^{-1}$, $200 \mathrm{mg} \cdot \mathrm{kg}^{-1}$ and $250 \mathrm{mg} \cdot \mathrm{kg}^{-1}$ lead to significant variation of body mass along the experiment, as compared to control group (Figure 1).

At Table I, it is observed the mean weight of organs of mice submitted to treatment. There was a statistically significant decrease of testicular weight in all animals treated with cyclophosphamide. In the same way, there was a significant decrease in the epididymides and liver weight of animals from groups C150, C200 and C250. There were no significant differences for the heart and lung weights; however, it was observed a decrease in the kidneys weight of all animals treated with cyclophosphamide.

(g)

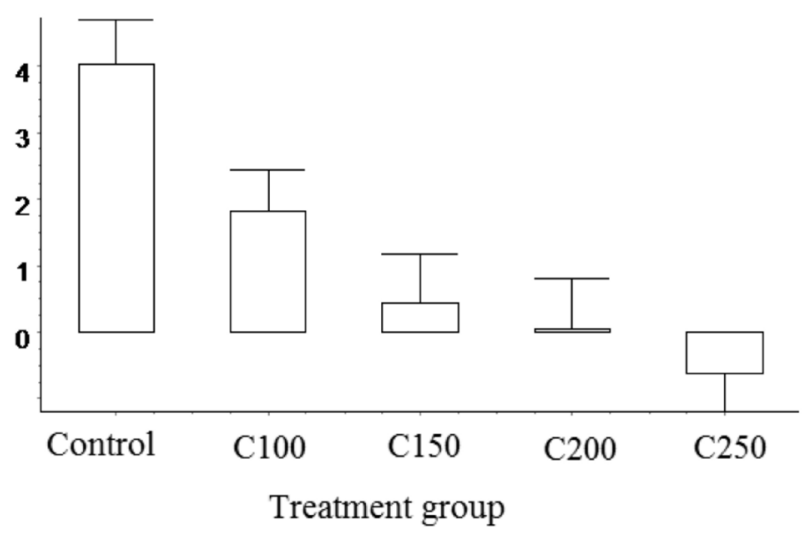

FIGURE 1 - Body mass variation in male mice treated with different concentrations of cyclophosphamide, for 6 weeks. Average values $\pm \mathrm{MSE}^{*}$. C100 cyclophosphamide $100 \mathrm{mg} . \mathrm{kg}^{-1}$, C150 cyclophosphamide 150 mg.kg ${ }^{-1}, \mathrm{C} 200$ cyclophosphamide $200 \mathrm{mg} \cdot \mathrm{kg}^{-1}, \mathrm{C} 250$ cyclophosphamide $250 \mathrm{mg} \cdot \mathrm{kg}^{-1}$ Test: ANOVA/Tukey; $\mathrm{p}<0.05 . *$ MSE $=$ Mean Standard Error

TABLE I-Evaluation of mean weight of organs, in grams, of male mice treated with different concentrations of cyclophosphamide.

\begin{tabular}{lccccc}
\hline Parameters & Control (10) & C100 (10) & C150 (10) & C200 (10) & C250 (10) \\
\hline Testicles $^{1}$ & $0.228 \pm 0.0169$ & $0.141 \pm 0.0091^{*}$ & $0.097 \pm 0.0094^{*}$ & $0.081 \pm 0.0082^{*}$ & $0.074 \pm 0.0042^{*}$ \\
Epididymides $^{2}$ & $0.086 \pm 0.0054$ & $0.105 \pm 0.0427$ & $0.057 \pm 0.0060^{*}$ & $0.049 \pm 0.0045^{*}$ & $0.050 \pm 0.0045^{*}$ \\
Heart $^{1}$ & $0.203 \pm 0.016$ & $0.166 \pm 0.009$ & $0.194 \pm 0.017$ & $0.165 \pm 0.007$ & $0.164 \pm 0.008$ \\
Kidney $^{1}$ & $0.569 \pm 0.023$ & $0.472 \pm 0.013^{*}$ & $0.465 \pm 0.017^{*}$ & $0.465 \pm 0.015^{*}$ & $0.449 \pm 0.035^{*}$ \\
Lung $^{1}$ & $0.278 \pm 0.020$ & $0.249 \pm 0.029$ & $0.261 \pm 0.024$ & $0.303 \pm 0.042$ & $0.234 \pm 0.028$ \\
Liver $^{1}$ & $2.067 \pm 0.093$ & $1.789 \pm 0.094$ & $1.701 \pm 0.081^{*}$ & $1.779 \pm 0.080^{*}$ & $1.567 \pm 0.134^{*}$ \\
\hline
\end{tabular}

C100 cyclophosphamide $100 \mathrm{mg} \cdot \mathrm{kg}^{-1}, \mathrm{C} 150$ cyclophosphamide $150 \mathrm{mg} \cdot \mathrm{kg}^{-1}, \mathrm{C} 200$ cyclophosphamide $200 \mathrm{mg} \cdot \mathrm{kg}^{-1}, \mathrm{C} 250$ cyclophosphamide $250 \mathrm{mg} \cdot \mathrm{kg}^{-1}$. Numerals between brackets indicate the number of utilized animals. *Statistically significant difference $(p<0.05)$. Mean values \pm MSE. Tests: ${ }^{1}$ Anova/Tukey, ${ }^{2}$ Kruskal-Wallis and Dunn 
In the fertility parameter, only the animals of the control group, $\mathrm{C} 100$ and $\mathrm{C} 150$ achieved to fertilize their female partners, being the fertility rate of 100, 70 and $30 \%$, respectively. The morphological analysis of spermatozoids contained in the epididymides tail presented alterations in all groups treated with the chemotherapeutic, being observed a higher incidence in the higher doses of cyclophosphamide, C200 and C250 (Figure 2). In the anomalous spermatozoids, the following head alterations were observed: amorphous, double, insertion, flag and microcephalus; the following tail alterations: comma, broken, rolled, tail node, double.

The parameters that aimed to evaluate the genotoxicity of cyclophosphamide on the male gamete are shown at Table II. In the analysis of parameters related to embryofetal development, it was observed that the numbers of implantations of groups $\mathrm{C} 100$ and $\mathrm{C} 150$ had a significant decrease respecting to control group. In the analysis of postimplantation losses rate, it was observed higher incidence in group $\mathrm{C} 150$, as well as the analysis of reabsorption rate

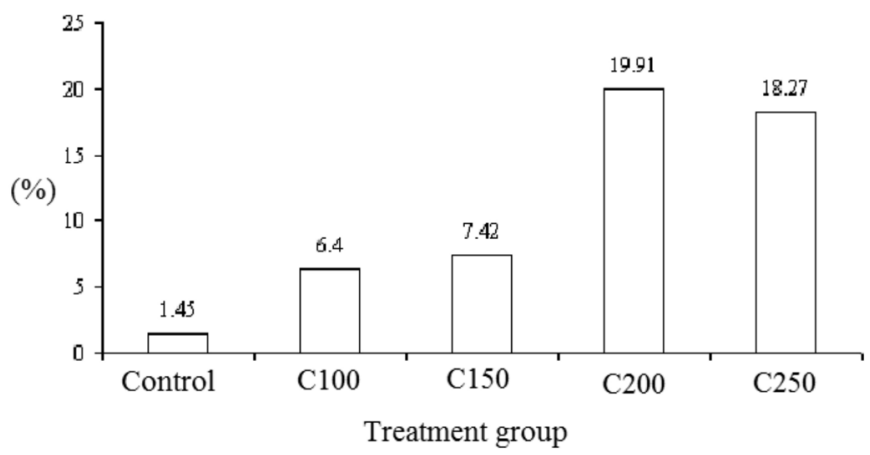

FIGURE 2 - Rate of abnormal spermatozoids in every experimental and control group. C100 cyclophosphamide $100 \mathrm{mg} \cdot \mathrm{kg}^{-1}, \mathrm{C} 150$ cyclophosphamide $150 \mathrm{mg} \cdot \mathrm{kg}^{-1}, \mathrm{C} 200$ cyclophosphamide $200 \mathrm{mg} \cdot \mathrm{kg}^{-1}$, C250 cyclophosphamide $250 \mathrm{mg} \cdot \mathrm{kg}^{-1}$ presented statistical difference for this same group. There was no statistically significant difference for the variables fetal length, fetal weight and placental index. Respecting to fetal viability, it was only observed statistical difference in the $\mathrm{C} 150$ treatment group. In the visceral analysis, only two malformations were observed: a fetus with absence of left eye in the control group and a fetus with gastroschisis in group C150. Besides, in the skeletal analysis, sternebrae were observed in butterfly shape, asymmetric, reduced and with bipartite ossification in the control, C100 and C150. However, these malformations occurred in isolated manner; therefore, they are not statistically significant.

\section{DISCUSSION}

In this study, it was investigated the toxicity of antineoplastic agent cyclophosphamide in adult male mice. The identification of cyclophosphamide effects on the germinative cells could help to clarify the mechanisms involved in the male infertility mediated by this drug toxicity.

The results have shown significant weight decrease of mice treated with cyclophosphamide, indicating that doses of 100, 150, 200 and $250 \mathrm{mg} \cdot \mathrm{kg}^{-1}$ were toxic for these animals. According to Manson, Kang (1994) and Chahoud et al. (1999), the body weight alterations are a usually observed indicative of toxicity in mice. It was verified also that the drug in high concentrations (200 and $250 \mathrm{mg} \cdot \mathrm{kg}^{-1}$ ) become the animals infertile, because the fertility rate of males in these groups was null. The effect of cyclophosphamide on fertility could be explained by the results obtained by Freire et al. (2006), according which the chemotherapeutic induces damage to DNA of germinative cells, and some of these cells are removed by apoptosis, resulting in decrease of mature spermatozoids (oligospermia or azoospermia). Camargo et al. (2006), have also concluded that cyclophosphamide is a strong

TABLE - II - Evaluation of parameters related to fetal development of male mice offspring treated with cyclophosphamide

\begin{tabular}{|c|c|c|c|c|c|}
\hline Parameters & Control & $\mathrm{C} 100$ & $\mathrm{C} 150$ & $\mathrm{C} 200$ & $\mathrm{C} 250$ \\
\hline Number of implantations & $10.500 \pm 0.817$ & $7.357 \pm 0.767^{*}$ & $4.857 \pm 1.100^{*}$ & 0 & 0 \\
\hline Fetal viability (\%) & $64.416 \pm 5.089$ & $47.119 \pm 9.992$ & $36.918 \pm 8.758^{*}$ & 0 & 0 \\
\hline Rate of post-implantation losses (\%) & $35.584 \pm 5.089$ & $56.022 \pm 9.819$ & $63.082 \pm 8.758^{*}$ & 0 & 0 \\
\hline Rate of reabsorption (\%) & $34.708 \pm 5.069$ & $47.578 \pm 9.642$ & $63.082 \pm 8.758^{*}$ & 0 & 0 \\
\hline Fetal length $(\mathrm{cm})$ & $2.632 \pm 0.030$ & $2.546 \pm 0.069$ & $2.618 \pm 0.043$ & 0 & 0 \\
\hline Fetal weight (g) & $0.998 \pm 0.021$ & $1.076 \pm 0.042$ & $1.095 \pm 0.075$ & 0 & 0 \\
\hline Placental index & $0.102 \pm 0.0548$ & $0.111 \pm 0.0992$ & $0.118 \pm 0.0346$ & 0 & 0 \\
\hline
\end{tabular}

C100 cyclophosphamide $100 \mathrm{mg} \cdot \mathrm{kg}^{-1}, \mathrm{C} 150$ cyclophosphamide $150 \mathrm{mg} \cdot \mathrm{kg}^{-1}, \mathrm{C} 200$ cyclophosphamide $200 \mathrm{mg} \cdot \mathrm{kg}^{-1}, \mathrm{C} 250$ cyclophosphamide $250 \mathrm{mg} \cdot \mathrm{kg}^{-1}$. *Statistically significant difference $(\mathrm{p}<0.05)$. Mean values $\pm \mathrm{MSE}$ 
agent promoter of infertility in mammalian, maintaining the individual infertile for a long post-treatment period or, in some cases, permanently, depending on both, the utilized dosage and exposition time do drug. The results of this research have shown that the risk for infertility was higher, in treatments with high doses of cyclophosphamide; which is consistent with Kenney et al. (2001), whom observed preservation of gonadal functions in patients receiving lower doses of the chemotherapeutic.

The low incidence of malformations resulting from applied doses in this study is at variance with some works in the literature, in which the alkylating agent cyclophosphamide is able to cause malformations in mice embryos (Hales, 1989; Kitchin et al., 1986), altering the intrauterine development. Kelly et al. (1992), have also demonstrated that the treatment in rats with low dose of the drug, during four weeks, increased the post-implantations losses and fetus death. Aguilar-Mahecha et al. (2002), have demonstrated that the exposition to this drug results in damage to male genome and induces hereditary mutations in the germinative lineage, leading to malformations. The results of this study that are discrepant with literature data could, probably, be due to possibility that administered doses had altered the fertility rate and spermatozoids quality. However, those spermatozoids achieving female fertilization resulted in fetuses with normal development.

Respecting to spermatozoids morphology, the treatment has shown that as the cyclophosphamide dose was increased, the rate of anomalous spermatozoids also increased. This could be explained by the fact that cyclophosphamide induces an abnormal spermatogenesis, and could, in some way, alter the spermatozoids development, producing so alterations on them (Schimenti et al., 1997).

All the groups treated with the chemotherapeutic presented testicular weight decrease; however, this effect was more accentuated in animals treated with higher doses $\left(200\right.$ and $\left.250 \mathrm{mg} \cdot \mathrm{kg}^{-1}\right)$. In the same way, there was a statistically significant decrease in the epididymides weight of animals from groups treated with concentration of 150,200 and $250 \mathrm{mg} \cdot \mathrm{kg}^{-1}$, as compared to control group. These results are in accordance with study developed by Kaur et al. (1997), whom observed a decrease in the weight testicles and epididymis tail, besides a decrease in the spermatic counting, motility and viability of spermatozoids, in response to cyclophosphamide treatment. Considering the differences in the numbers of implantations between the different study experimental groups, it is supposed that cyclophosphamide in the utilized doses effectively influenced the animals spermatogenesis, leading them to a state of infertility or subfertility. The interference of chemotherapeutic during the spermatoge- nesis process was evidenced through the morphological alterations found in spermatozoids of animals treated with the drug. These same alterations were observed in the studies of Vigi and Bustos-Obregon (1985), which showed occurrence of infertility associated to gametes malformations in animals treated with high doses of the chemotherapeutic.

It was observed significant decrease in the fetal viability, with the dose of $150 \mathrm{mg} \cdot \mathrm{kg}^{-1}$, respecting to control treatment, resulting in a higher index of post-implantation losses and reabsorption rate. This result suggests that cyclophosphamide could cause damages to developing fetuses, leading them to death. It is clear that cyclophosphamide, in the doses utilized in this study, decreased the fertility of animals and influenced also in the number of implantations. Data respecting the negative effects of cyclophosphamide on intrauterine development, such as presence of congenital malformations, toxicity and mutagenicity, are described in the literature by Porter and Singh (1988).

The hepatotoxicity observed in this present study after administration of cyclophosphamide, is related with production of two metabolites, 4-hydroxycyclophosphamide and acrolein (DeLeve et al., 1996). In the same way, George et al. (2003) observed in their study that exposition to toxic metabolites of cyclophosphamide leads to increase in liver toxicity and mortality, decreasing so the patients' survival.

The cyclophosphamide affects also the kidneys, promoting lesions, sometimes irreversible. The renal toxicity observed in this present study is related to nephrotoxic and/ or vesical toxic effect of the drug, as reported by Costa et al. (2004). According to Antunes \& Bianchi (2004), the nephrotoxicity is one of the main side-effects of therapy with cisplatin, an antineoplastic drug as well as cyclophosphamide. Based on employed methodology and obtained results, it is possible to conclude that cyclophosphamide leads to a decrease in body weight and testicles weight, in all administered concentrations, at doses of 150, 200 and $250 \mathrm{mg} . \mathrm{kg}^{-1}$; it decreases also epididymides and liver weights; alters the morphology of spermatozoids compromising so the fertilization; presents toxicity for liver and kidneys and, in addition, decreases fetal viability increasing so the reabsorption rate; however, this chemotherapeutic didn't cause significant malformations in the offspring of treated males.

\section{REFERENCES}

ADLER, D. Spermatogenesis and mutagenicity of environmental hazards: extrapolation of genetic risk from mouse to man. Andrologia, v.32, p.233-237, 2001. 
ALLISON, A.C. Immunosuppressive drugs: the first 50 years and a glance forward. Immunopharmacology, v.47, p.63$83,2000$.

AGUILAR-MAHECHA, A.; HALES, B.F.; ROBAIRE, B.: Chronic cyclophosphamide treatment alters the expression of stress response genes in rat male germ cells. Biol. Reprod., v.66, p.1024-32, 2002.

ANDERSON, D. Male-mediated developmental toxicity. Toxicol. Appl. Pharmacol., v.207, n.2, p.506-513, 2005.

ANDERSON, D.; BISHOP, J.B.; GARNER, R.C.; O S T R O S K Y W E G A N, P.; S E L B Y, P. B. Cyclophosphamide - Review of its mutagenicity for an assessment of potential germ cell risks. Mutat. Res., v.330, p.115-181, 1995.

ANTUNES, L.M.G.; BIANCHI, M.L.P. Antioxidantes da dieta como inibidores da nefrotoxicidade induzida pelo antitumoral cisplatina. Rev. Nutr., v.17, p.89-96, 2004.

BACH, J.F.; STROM, T. The mode of action of immunosuppressive agents. Amsterdam: Elsevier, 1986. 379 p.

BARROW, M.V.; TAYLOR, W.I.. A rapid method for detecting malformation in rat fetuses. J. Morph., v.127, p.291-306, 1969.

CAMARGO, I.C.C.; NOGUEIRA, L.C.; PONTES, D.A.; FAVARETO, A.P.A.; FREI, F.; MESQUITA S.F.P. Morfometria e estereologia testicular de ratos adultos tratados com ciclofosfamida incorporada ao lipossoma. Semin., Ciênc. Biol. Saúde, v.27, p.105-116, 2006.

CHAHOUD, I.; LIGENSA, A.; DIETZEL, L.; FAQUI, A.S. Correlation between maternal toxicity and embryo/fetal effects. Reprod. Toxicol., v.13, p.375-381, 1999.

CHAUBE, S.; KURY, G.; MURPHY, M. L. Teratogenic effects of cyclophosphamide (NSC-26271) in the rat. Cancer Chemoter. Rep., v.51, p.363, 1967.

COSTA, K.S.; GARCIA, R.I.D.; CECATTO, S.B.; RAPOPORT, P.B.; MENDONÇA, R. Disacusia sensorioneural autoimune em crianças: Relato de caso. Rev. Bras. Otorrinolaringol., v.70, p.394-397, 2004.
DELEVE, L.D.; WANG, X.D.; HUYBRECHTS, M.M. Cellular target of cyclophosphamide toxicity in the murine liver: role of glutathione and site of metabolic activation. Hepatology, v.24, p.830-837, 1996.

FAIRLEY, K.F.; BARRIE, J.U.; JOHSON, W. Sterility and testicular atrophy related to cyclophosphamide therapy. Lancet, v.1, p.568-569, 1972.

FAGUNDES F.A.; OLIVEIRA, L.B.; CUNHA, L.C. VALADARES M.C. Annona coriacea induz efeito genotóxico em camundongos. Rev. Eletron. Farm., v.2, p.24-29, 2005.

FREIRE, E. A. M.; NEPOMUCENO, J. C. A.; MAIA, I. O.; CICONELLI, R. M. Rheumatic diseases and male infertility - review article. Rev. Bras. Reumatol., v.46, p.12-20, 2006.

GEORGE, B.; MCDONALD, J.T. SLATTERY, M.E. BOUVIER, S.R.; AMI L.; BATCHELDER, T.F.; KALHORN, H.; SCHOCH, G.; ANASETTI, C.; GOOLEY, T. Cyclophosphamide metabolism, liver toxicity, and mortality following hematopoietic stem cell transplantation. Blood, v.101, p.2043-2048, 2003.

HALES, B.F. Effects of phosphoramide mustard and acrolein, cytotoxic metabolites of cyclophosphamide, on mouse limb development in vitro. Teratology, v.40, p11-20, 1989.

HARDMAN, J.G.; LIMBIRD, L.E. Quimioterapia das doenças neoplásicas: antineoplásicos. In: GOODMAN, L.S.; GILMAN, A. As bases farmacológicas da terapêutica. 10 ed. Rio de Janeiro: McGraw Hill, 2003. p.1041-1097.

KAUR, F.; SANGHA, G.K.; BILASPURI, G.S. Cyclophosphamide-induced structural and biochemical changes in the testis and epididymis of rats. Indian J. Exp. Biol., v.35, p.771-775, 1997.

KELLY, S.M.; ROBAIRE, B.; HALES, B.F. Paternal cyclophosphamide treatment causes post-implantation loss via inner cell mass-specific cell death. Teratology, v.45, p.313-318, 1992.

KENNEY, L.B.; LAUFER, M.R.; GRANT, F. D.; GRIER, H.; DILLER, L. High risk of infertility and long term gonadal damage in males treated with high dose cyclophosphamide for sarcoma during childhood. Cancer, v.91, p.713-621, 2001. 
KITCHIN, K.T.; SCHMID, B.P.; SANYAL M.K. Rodent wholeembryo culture as a teratogen screenin method. Methods Find. Exp. Clin. Pharmacol., v.8, p.291-301, 1986.

MANSON, J.M.; KANG, Y.J. Test methods for assessing female reproductive and developmental toxicology. In: HAYES, A.W. Ed. Principles and methods of toxicology. 3.ed. New York: Raven Press., 1994. cap.28, p.989-1037.

PORTER, A.J.; SINGH, S.M. Transplacental teratogenesis and mutagenesis in mouse fetuses treated with cyclophosphamide. Teratog. Carcinog. Mutagen., v.8, p.191-203, 1988.

RANG, H.P.; DALE, M.M.; RITTER, J.M.; MOORE, P.K. Farmacologia. 6.ed. Rio de Janeiro: Elsevier, 2007. 920 p.

SCHAMBERG, R.C.; ROSEMBERG, S.A.; SEIPP, C.A. Effects of high dose methotrexate and vincristine on ovarian and testicular functions in patients undergoing postoperative adjuvant treatment of osteosarcoma. Cancer Treat. Rev., v.65, p.739-746, 1981.

SCHIMENTI, K.J.; HANNEMAN, W.H.; SCHIMENTI, J.C. Evidence for cyclophosphamide-induced gene conversion and mutation in mouse germ cells. Toxicol. Appl. Pharmacol., v.147, p.343-350, 1997.

STAPLES, R.E.; SCHNELL, V.L. Refinements in rapid clearing technic in the $\mathrm{KOH}$-alizarin red $\mathrm{S}$ method for fetal boné. Stain Technol., v.39, p.61-63, 1964.
TAYLOR, P. Skeletal examination. In: Practical Teratology. New York: Academic Press, 1986. p.77-100

TRASLER, J.M.; HALES, B.F.; ROBAIRE, B. Paternal cyclophosphamide treatment of rats causes fetal loss and malformation without affecting male fertility. Nature, v.316, p.144-146, 1985.

TRASLER, J.M.; HERMO, L.; ROBAIRE, B. Morphological changes in the testis and epididymis of rats treated with cyclophosphamide: a quantitative approach. Biol. Reprod., v.38, p.463-479, 1988.

VIGIL, P.; BUSTOS-OBREGON, E. Alkylating Agents and mouse Spermatogenesis: Effects of a Single Dose of Cyclophosphamide. Andrologia, v.17, p.276-282, 1985.

WILSON, J.G. Methods for administering agents and detecting malformations in experimental animals. In: WILSON, J. G., WARKANY, J. (Eds.). Teratology: principles and techniques. Chicago: The University of Chicago Press, 1965. $288 \mathrm{p}$.

WYROBEK, A.J.; GORDON, L.A.; BURKHART, J.G. An evaluation of the mouse sperm morphology test and other sperm in non-human mammals: A reported of the US EPA Gene-Tox-Program. Mutat. Res., v.115, p.1-72, 1983.

Received for publication on $23^{\text {th }}$ july 2008 Accepted for publication on $07^{\text {th }}$ november 2008 